\title{
PENGARUH CORPORATE GOVERNANCE DAN STRUKTUR KEPEMILIKAN TERHADAP ASIMETRI INFORMASI
}

\author{
Ana Pratiwi \\ Universitas Brawijaya \\ e-mail: anapratiwie@gmail.com \\ Nurkholis \\ Universitas Brawijaya \\ e-mail: hnurkholis_ub@yahoo.com \\ Abdul Ghofar \\ Universitas Brawijaya \\ e-mail: abdulghofar@yahoo.com
}

\begin{abstract}
This research aims to test the effect of corporate governance and ownership structure on information asymmetry. Corporate governance is proxied by the ASEAN corporate governance scorecard, and ownership structure is proxied by institutional ownership and managerial ownership. This research adds control variables such as company size, trading volume, and variant return. The population of this research is companies that have score from ASEAN Corporate Governance Scorecard in 2010-2011. Research samples are determined by purposive sampling method and there are 120 companies fulfill the research criteria. Analysis method used in this research is Multiple Regression Analysis. The findings show that the corporate governance and institutional ownership have no impact on the asymmetric information. On the contrary, managerial ownership has negative and significant affect on the asymmetric information. It is also found that the control variables, the size and volume of trading companies have no effect on asymmetric information but return variant has negative affect on asymmetric information.
\end{abstract}

Keywords: corporate governance, institutional ownership and managerial ownership, asymmetric information.

http://dx.doi.org/10.20885/jaai.vol19.iss2.art2

\begin{abstract}
Abstrak
Penelitian ini bertujuan menguji pengaruh corporate governance dan struktur kepemilikan terhadap asimetri informasi. Corporate governance diproksikan dengan ASEAN Corporate Governance Scorecard sedangkan struktur kepemilikan diproksikan dengan kepemilikan institusional dan kepemilikan manajerial. Penelitian ini menambahkan variabel kontrol yaitu ukuran perusahaan, volume perdagangan, dan varian return. Populasi dalam penelitian ini adalah perusahaan yang memiliki skor dari ASEAN Corporate Governance Scorecard pada tahun 2010 dan 2011. Sampel penelitian ini dipilih dengan menggunakan purposive sampling dan diperoleh 120 perusahaan yang memenuhi kriteria penelitian. Metode analisis yang digunakan adalah Multiple Regression Analysis. Hasil penelitian menunjukkan bahwa corporate governance dan kepemilikan institusional tidak terbukti berpengaruh negatif terhadap asimetri informasi. Sedangkan kepemilikan manajerial terbukti berpengaruh negatif dan signifikan terhadap asimetri informasi. Hasil penelitian dari variabel kontrol ukuran perusahan dan volume perdagangan tidak berpengaruh terhadap asimetri informasi, sedangkan varian return berpengaruh negatif terhadap asimetri informasi.
\end{abstract}

Kata kunci: Corporate governance, kepemilikan institusional dan kepemilikan manajerial, asimetri informasi. 


\section{PENDAHULUAN}

Ditinjau dari sudut pandang teori keagenan, asimetri informasi dilatarbelakangi oleh terganggunya proses komunikasi informasi antara principal dan manajer. Terganggunya proses komunikasi ini merupakan akibat dari tindakan manajer sebagai pengelola perusahaan yang mengetahui lebih banyak informasi internal ataupun prospek perusahaan, namun tidak memberikan informasi yang sebenarnya mengenai kondisi perusahaan kepada principal dan stakeholders (Ujiyanto dan Pramuka 2007). Tindakan manajer yang cenderung tidak memberikan informasi yang jelas kepada principal dilakukan manajer karena manajer cenderung melaporkan dan melakukan tindakan untuk memaksimalkan utilitasnya (Wisnumurti 2010). Arifin dan Rahmawati (2006) mengungkapkan bahwa ketergantungan pihak eksternal terutama pemilik pada angka akuntansi, kecenderungan manajer untuk memaksimalkan keuntungan sendiri dan tingkat asimetri informasi yang tinggi menyebabkan keinginan besar bagi manajer untuk memanipulasi laporan untuk kepentingan pribadi.

Asimetri informasi antara manajemen dan principal dapat memberi peluang bagi manajer dalam melakukan tindakan untuk memperoleh keuntungan pribadi. Contoh kasus-kasus pelanggaran yang dilakukan oleh manajer karena adanya asimetri informasi yang ada di Indonesia antara lain kasus Bank Century dan kasus mark-up laporan keuangan PT. Indofarma yang overstated. Kedua kasus tersebut terjadi karena ada salah satu pihak yang memiliki informasi lebih banyak daripada pihak lainnya. Dalam kasus Bank Century, asimetri informasi terjadi saat Robert Tantular melakukan pemecahan deposito milik Sampoerna, yang dilakukan karena mengetahui bahwa Bank Century sedang tidak sehat. Pemecahan deposito tersebut dimaksudkan untuk mendapat penggantian dari LPS, dan mengindikasikan adanya pencucian uang sedangkan dalam kasus PT. Indofarma, pihak manajemen melakukan penggelembungan laba bersih tahunan.
Contoh kasus-kasus tersebut merupakan cerminan adanya ketidakterbukaan informasi serta adanya benturan kepentingan dan keinginan (conflict of interest) antara agent dan principal yang tidak diungkapkan kepada publik secara jelas, terutama kepada para investor. Untuk mengantisipasi terjadinya asimetri informasi, diperlukan suatu mekanisme yang dapat meminimalkan tingkat asimetri informasi yang dilakukan oleh agent kepada principal. Salah satu mekanisme yang dapat digunakan adalah konsep corporate governance yang merupakan sistem, struktur, dan proses yang terintegrasi untuk mewujudkan kelima prinsip utama dari corporate governance, yaitu transparency, accountability, responsibility, independency, dan fairness. Pelaksanaan corporate governance meemlukan adanya struktur yang ideal seperti komisaris independen, komite audit, direksi, dan komite penunjang lainnya.

Penerapan good corporate governance mendorong terciptanya persaingan yang sehat dan iklim usaha yang kondusif. Konsep corporate governance ini pada intinya menginginkan adanya transparansi yang lebih baik bagi semua pengguna laporan keuangan yang jika berhasil diterapkan dengan baik akan meningkatkan kinerja dan nilai dari perusa haan. Sistem corporate governance akan memberikan perlindungan terhadap pemegang saham dan kreditor pada investasi yang telah mereka lakukan. Kanagaretnam, Gerald, dan Dennis (2007) menjelaskan bahwa konsep corporate governance merupakan kontrol serta prosedur yang memastikan bahwa tindakan yang dilakukan menajemen atau agent merupakan tindakan yang mengikuti kepentingan pemilik saham atau principal. Indonesian Institute for Corporate governance (IICG) mendefinisikan corporate governance (CG) sebagai serangkaian mekanisme untuk mengarahkan dan mengendalikan suatu perusahaan agar operasional perusahaan berjalan dengan baik sesuai dengan harapan para pemangku kepentingan atau stakeholders (www.iicg.org).

Karena asimetri informasi sulit dihindari, corporate governance selalu dibutuhkan 
baik oleh perusahaan kecil maupun besar, bahkan perusahaan yang tidak terdaftar di Bursa Efek pun perlu menerapkan prinsipprinsip corporate governance. Dalam kurun waktu beberapa tahun terakhir ini, corporate governance menjadi perhatian yang serius dikarenakan terjadinya kegagalan penerapan prinsip-prinsip corporate governance. Berbagai pihak diantaranya regulator dan pemegang saham terus menekan agar prinsipprinsip good corporate governance terus ditingkatkan dan diterapkan (Cai et al. 2008). Penelitian tentang corporate governance juga terus dikembangkan. Kanagaretnam, Gerald, dan Dennis (2007) menemukan bahwa perusahaan yang memiliki nilai penerapan corporate governance yang baik akan memiliki tingkat asimetri informasi yang rendah dalam kurun waktu pengumuman laba triwulan.

Menurut Jensen, Solberg, dan Zorn (1992) dan Crutchley dan Hansen (1989) konflik kepentingan antara manajer dan agent juga dapat dikurangi dengan meningkatkan kepemilikan manajerial dan kepemilikan institusional, dalam hal ini sebagai monitoring agents. Disini peningkatan kepemilikan manajerial akan mensejajarkan kedudukan manajerial dengan pemegang saham, sehingga pihak manajerial akan bertindak sesuai dengan kepentingan pemegang saham.

Peningkatan struktur kepemilikan dalam suatu perusahaan diharapkan akan membuat manajer dapat bertindak sesuai dengan keinginan pemegang saham, karena manajer secara otomatis akan termotivasi untuk meningkatkan kinerja. Peningkatan struktur kepemilikan juga dapat menjadi pengawas bagi manajemen yang akan berdampak mengurangi motivasi manajer untuk melakukan kecurangan, sehingga asimetri informasi dapat berkurang.

Perusahaan yang memiliki corporate governance yang baik akan memberikan implikasi tersajinya informasi yang lebih baik sehingga diharapkan dapat menurunkan tingkat asimetri informasi antara principal dan agent. Salah satu penelitian mengenai pengaruh corporate governance terhadap asimetri informasi dilakukan oleh Kanagaretnam,
Gerald, dan Dennis (2007). Penelitian tersebut menggunakan bid ask spread dan depths yang merupakan proksi dari penurunan asimetri informasi, sedangkan corporate governance diproksikan oleh komisaris independen, struktur dewan, dan aktivitas dewan. Untuk analisis bid ask spread, Kanagaretnam, Gerald, dan Dennis (2007) menggunakan ukuran perusahaan, volatilitas dan harga saham sebagai variabel kontrol. Sedangkan untuk analisis depths, menggunakan saham yang beredar dan volume perdagangan sebagai variabel kontrol. Hasilnya menunjukkan bahwa corporate governance berpengaruh negatif dan signifikan terhadap asimetri informasi di sekitar pengumuman laba triwulanan. Kanagaretnam, Gerald, dan Dennis (2007) menunjukkan bahwa corporate governance yang berjalan efektif akan meningkatkan kualitas dan frekuensi informasi yang diterbitkan oleh manajemen. Semakin baik pelaksanaan corporate governance oleh perusahaan, maka semakin banyak informasi yang diungkapkan. Atau dapat disimpulkan bahwa semakin baik perusahaan menerapkan corporate governance maka semakin rendah pula tingkat asimetri informasi yang terjadi.

Penelitian ini adalah pengembangan dari penelitian yang dilakukan oleh Kanagaretnam, Gerald, dan Dennis (2007) yang meneliti pengaruh struktur corporate governance terhadap asimetri informasi dengan menggunakarsampel perusahaan yang terdaftar NYSE atau AMEX dengan periode penelitian pada bulan Juni dan September tahun 2000. Variabel corporate governance yang digunakan meliputi komisaris independen, struktur dewan, dan aktivitas dewan.

Penelitian ini memproksikan Corporate governance dengan skor ASEAN Corporate Governance Scorecard untuk Indonesia (indeks corporate governance), kepemilikan institusional, dan kepemilikan manajerial dengan mengambil periode penelitian tahun 2010-2011. Penelitian ini menggunakan sampel perusahaan-perusahaan publik di Indonesia yang terdaftar di Bursa Efek Indonesia yang masuk dalam daftar ASEAN corporate governance scorecard, yaitu daftar yang dibuat oleh 
Indonesian Institute for Corporate Directorship (IICD), sebagai Domestic Body ASEAN corporate governance scorecard yang telah melakukan penilaian terhadap tata kelola perusahaan terbuka di Indonesia yang didukung oleh Asian Development Bank dan kemudian ditunjuk oleh Otoritas Jasa Keuangan (OJK) untuk melanjutkan penilaian tersebut. Penelitian ini menggunakan data pada periode tahun 2010-2011. Periode dalam penelitian ini terbatas dikarenakan untuk periode 2012 pihak regulator yaitu OJK belum merilis data tersebut. Jadi data periode yang diambil peneliti hanya 2 tahun.

\section{TINJAUAN PUSTAKA DAN PERUMUSAN HIPOTESIS}

Asimetri informasi antara agent dan principal dapat dikurangi dengan penerapan corporate governance yang berkualitas dan baik. Penerapan corporate governance disini dapat dijadikan struktur, sistem serta proses yang berintegrasi untuk mewujudkan pelaporan keuangan yang transparan, akuntabilitas, bertanggung jawab, independen, dan adil. Corporate governance merupakan perlindungan terhadap investasi yang dilakukan. Sehingga mekanisme corporate governance diarahkan untuk mengurangi asimetri informasi antara principal dan agent.

Dalam teori agensi yang dikemukakan oleh Jensen dan Meckling (1976) telah diungkapkan bahwa dalam dunia bisnis terjadi fenomena oportunis dan manusia sebagai individu cenderung untuk memenuhi utilitasnya secara maksimal. Hal ini mengakibatkan adanya distribusi informasi yang tidak merata antara agent dan principal.

Distribusi informasi yang tidak merata juga disebut sebagai asimetri informasi. Asimetri informasi adalah suatu keadaan dimana agent mempunyai informasi tentang perusahaan lebih banyak daripada principal. Agent disini dapat juga mengetahui prospek tentang perusahaan di masa depan. Kondisi ketimpangan informasi ini juga dapat memberikan peluang kepada agent untuk memanipulasi pelaporan untuk memaksimalkan utilitasnya.
Bukti empiris tentang pengaruh corporate governance terhadap asimetri informasi diantaranya dinyatakan oleh Kanagaretnam, Gerald, dan Dennis (2007), yang meneliti pengaruh corporate governance terhadap asimetri informasi pada perusahaan yang terdaftar di NYSE atau AMEX dengan periode penelitian bulan Juni dan September tahun 2000. Penelitian ini menunjukkan adanya pengaruh negatif antara corporate governance dan asimetri informasi. Selain itu ada penelitian lain yaitu dari Purwanti (2013) yang membuktikan adanya pengaruh negatif antara corporate governance dan asimetri informasi.

Penggunaan variabel penelitian menggunakan ASEAN CG Scorecard ini karena perusahaan-perusahaan yang mengikuti pemeringkatan ini mengindikasikan bahwa perusahaan-perusahaan tersebut telah melakukan penerapan corporate governance dengan baik. ASEAN corporate scorecard adalah indeks berupa presentase dengan skala 1\%-100\% yang dikeluarkan oleh IICD yang merupakan domestic body dari ASEAN CG scorecard Sedangkan struktur kepemilikan (kepemilikan manajerial dan kepemilikan institusional) oleh beberapa peneliti dipercaya dapat mempengaruhi jalannya perusahaan yang akhirnya berpengaruh terhadap tingkat asimetri informasi.

\section{Perumusan Hipotesis}

Dalam penelitiannya, Kanagaretnam, Gerald, dan Dennis (2007) menunjukkan bahwa penerapan corporate governance yang berkualitas akan menurunkan asimetri informasi. Hal ini dikarenakan jika corporate governance yang dilakukan oleh perusahaan berkualitas, maka pengungkapan yang dilakukan oleh perusahaan akan transparan. Sehingga dapat dikatakan informasi yang dimiliki oleh investor benar-benar mencerminkan perusahaan tempat mereka berinvestasi.

ASEAN corporate governance scorecard adalah indeks berupa presentase dengan yang dikeluarkan oleh IICD yang merupakan domestic body dari ASEAN CG scorecard. Penilaian corporate governance berdasarkan insiatif dari ASEAN Capital Market Forum (ACMF) yang beranggotakan para regulator 
pasar modal di negara ASEAN. Penilaian ini juga telah digunakan untuk menilai praktek corporate governance perusahaan terbuka di negara ASEAN lainnya yaitu Filipina, Malaysia, Singapura, Thailand dan Vietnam.

Selanjutnya, Klein, Shapiro, dan Young (2005) menggunakan indeks GMI (Governance Metrics International) sebagai proksi untuk corporate governance. Penelitian tersebut dilakukan di Kanada yang menunjukkan hasil tidak ada pengaruh yang signifikan, tetapi Klein, Shapiro, dan Young (2005) menyimpulkan bahwa corporate governance secara umum dapat mengurangi asimetri informasi.

Dengan adanya pengukuran yang dipublikasikan tentang corporate governance, maka kepercayaan investor terhadap perusahaan akan meningkat. Dengan kata lain, perusahaan yang mempublikasikan indeks pengukuran corporate governace dipercaya akan memiliki tingkat asimetri informasi yang lebih kecil. Maka berdasarkan hasil penelitianpenelitian tersebut maka dalam penelitian ini disusun hipotesis berikut:

H1: Corporate governance berpengaruh negatif terhadap asimetri informasi

Konflik kepentingan mendasari adanya biaya keagenan, dengan asumsi rasionalitas ekonomi dimana orang yang akan mendahulukan kepentingannya terlebih dahulu sebelum kepentingan orang lain. Demikian juga dengan manajemen perusahaan. Teori keagenan menyatakan bahwa sulit untuk mempercayai bahwa manajemen akan selalu bertindak berdasarkan kepentingan pemegang saham. Karena hal tersebut, maka diperlukan pengawasan dari pemegang saham sehingga konflik keagenan yang terjadi dapat dikurangi (Copeland dan Weston 1992).

Kepemilikan institusional adalah jumlah kepemilikan suara suatu institusi terhadap perusahaan. Dalam penelitian ini, kepemilikan institusional diproksikan dengan menggunakan presentase kepemilikan saham institusi di perusahaan. Peningkatan kepemilikan institusional menyebabkan kinerja manajer diawasi secara optimal dan terhindar dari perilaku oportunistik. Dengan adanya kepemilikan institusional manajer akan bertindak sesuai dengan kepentingan pemegang saham.

Henry (2010); Singh dan Davidson (2003); Knight dan Weir (2009) melakukan penelitian yang menunjukkan hasil bahwa kepemilikan institusional berpengaruh terhadap agency conflict. Agency conflict disini akan berpengaruh terhadap tersalurnya asimetri informasi antara manajer dan principal. Selain itu Klein, Shapiro, dan Young (2005) juga menyebutkan bahwa kepemilikan institusional dalam suatu perusahaan dapat mengurangi adanya asimetri informasi dalam perusahaan.

Di Indonesia, Purwanti (2013) juga melakukan penelitian yang menguji pengaruh kepemilikan institusional terhadap asimetri informasi dan hasilnya tidak terdapat pengaruh negatif antara kepemilikan institusional terhadap asimetri informasi. Perusahaan dengan struktur kepemilikan yang tinggi memiliki tekanan yang lebih tinggi untuk memberikan pengungkapan yang lebih baik (Purwanti, 2013). Dengan pengungkapan yang lebih baik akan meningkatkan transparansi. Transparansi yang baik akan menurunkan tingkat asimetri informasi. Maka berdasarkan hasil penelitian-penelitian tersebut maka dalam penelitian ini disusun hipotesis berikut:

H2: Kepemilikan institusional berpengaruh negatif terhadap asimteri informasi

Kepemilikan manajerial merupakan jumlah saham yang dimiliki oleh manajemen. Dalam suatu perusahaan, jika didalamnya terdapat kepemilikan manajerial maka informasi yang diberikan kepada publik akan lebih banyak. Jensen dan Meckling (1976) menyatakan bahwa untuk mengurangi konflik antara principal dan agent dapat dilakukan dengan cara meningkatkan jumlah kepemilikan manajerial dalam perusahaan. Menurut Crutchley dan Hansen (1989) dan Jensen, Solberg, dan Zorn (1992) perusahaan meningkatkan kepemilikan manajerial untuk mensejajarkan kedudukan para manager dengan pemegang saham sehingga bertindak sesuai keinginan pemegang saham. Dengan pening- 
katan presentase kepemilikan manajerial, para manajer termotivasi untuk meningkatkan kinerja dan bertanggung jawab meningkatkan kemakmuran pemegang saham.

Henry (2010); Singh dan Davidson (2003); Knight dan Weir (2009) melakukan penelitian yang menunjukkan hasil bahwa kepemilikan manajerial berpengaruh terhadap agency conflict. Agency conflict disini akan berpengaruh terhadap tersalurnya asimetri informasi antara manager dan principal. Semakin tinggi kepemilikan manajerial dalam suatu perusahaan maka akan semakin kecil asimetri informasi dalam perusahaan tersebut.

Dalam penelitiannya, Purwanti (2013) menyimpulkan bahwa kepemilikan manajerial berpengaruh negatif terhadap asimetri informasi. Semakin tinggi kepemilikan manajerial suatu perusahaan maka tingkat asimetri informasi dalam perusahaan tersebut akan semakin rendah. Kekayaan pribadi manajemen yang terkait dengan nilai perusahaan dalam bentuk saham diharapkan akan membuat manajemen untuk bertindak demi meningkatkan nilai perusahaan sehingga dapat mengurangi konflik keagenan. Konflik keagenan yang berkurang dapat mengurangi asimetri informasi antara agent dan principal. Maka berdasarkan hasil penelitian-penelitian tersebut maka dalam penelitian ini disusun hipotesis berikut:

H3: Kepemilikan Manajerial berpengaruh negatif terhadap Asimetri informasi

\section{METODA PENELITIAN}

\section{Populasi dan Sampel}

Populasi penelitian ini adalah seluruh perusahaan publik yang terdaftar dalam ASEAN corporate scorecard. Jumlah perusahaan yang memiliki indeks ASEAN CG Scorecard antara tahun 2010-2011 adalah 155 perusahaan.

Pemilihan sampel penelitian ini menggunakan purposive sampling dengan tujuan mendapatkan sampel yang representatif sesuai dengan kriteria sampel yang telah ditentukan oleh peneliti. Penggunaan metode purposive sampling dalam penelitian ini karena sampel yang digunakan diharapkan akan memberikan hasil yang lebih valid dan tidak bias. Kriteria- kriteria yang digunakan untuk memilih perusahaan yang dijadikan sampel dalam penelitian ini adalah: (1) Perusahaan yang termasuk dalam ASEAN corporate governance scorecard pada tahun 2010-2011. Kelompok perusahaan tersebut adalah hasil survey yang dilakukan oleh Indonesian Institute of Corporate Directorship (IICD) yang merupakan domestic body dari ASEAN CG Scorecard. (2) Perusahaan yang mempublikasikan Laporan Tahunan (Annual Report) untuk periode 31 Desember 2010-2011. (3) Perusahaan yang menggunakan mata uang Rupiah dalam Laporan Tahunannya untuk periode 31 Desember 2010-2011. (4) Data yang tersedia lengkap (data secara keseluruhan tersedia dalam Laporan Tahunan periode 2010-2011 baik data untuk corporate governance dan struktur kepemilikan maupun data untuk asimetri informasi).

\section{Variabel Penelitian dan Pengukuran}

Variabel dependen dalam penelitian ini adalah asimetri informasi. Asimetri informasi adalah suatu keadaan dimana agent memiliki informasi yang lebih banyak tentang perusahaan dimasa yang akan datang dibandingkan dengan principal (Richardson 1998). Penelitian ini mengukur asimetri informasi dengan menggunakan bid-ask spread. Model untuk menyesuaikan perhitungan Asimteri Informasi (Kanagaretnam, Gerald, and Dennis 2007) dalam penelitian ini adalah sebagai berikut:

Asimetri Informasi $=($ Ask-bid $) /\{($ Ask + bid $) / 2\}$

Ask adalah Harga permintaan tertinggi saham perusahaan i pada tahun $\mathrm{t}$

Bid adalah Harga penawaran terendah saham perusahaan I pada tahun $\mathrm{t}$

Variabel independen yang digunakan dalam penelitian ini ada 3 (tiga), yaitu: 1) Corporate governance. Corporate governance dalam penelitian ini diukur dengan menggunakan ASEAN corporate governance scorecard. ASEAN Corporate Governance Scorecard adalah indeks berupa prosentase dengan skala $1 \%-100 \%$ yang dikeluarkan oleh IICD yang merupakan domestic body dari ASEAN CG 
Scorecard. Penilaian corporate governance yang merupakan inisiatif dari ASEAN Capital Market Forum (ACMF) yang beranggotakan para regulator pasar modal di negara ASEAN (IICD 2014). 2) Kepemilikan Manajerial. Kepemilikan Manajerial adalah jumlah kepemilikan saham oleh pihak manajemen dari seluruh modal saham yang ada di perusahaan (Gideon dan Milgrom 1985). Ada atau tidaknya kepemilikan manajerial terhadap suatu perusahaan merupakan suatu mekanisme yang digunakan untuk mengurangi konflik keagenan. Jika manajemen memiliki kekayaan di perusahaan, maka diharapkan manajemen akan bertindak lebih transparan untuk kepentingannya. 3) Kepemilikan Institusional. Kepemilikan institusional merupakan jumlah kepemilikan suara suatu institusi terhadap perusahaan (Beiner et al. 2003). Dalam penelitian ini, kepemilikan institusional diukur dengan menggunakan persentase kepemilikan saham suatu institusi di perusahaan.

Sedangkan variabel Kontrol yang digunakan dalam penelitian ini ada tiga, yaitu: (1) ukuran perusahaan (size) yang diukur dengan total asset perusahaan; (2) volume perdagangan yaitu penutupan pasar bulanan yang kemudian dirata-rata dalam satu tahun,dan; (3) varian return yang diukur dengan:

$\mathrm{R}=\left(\mathrm{P}_{\mathrm{t}}-\mathrm{P}_{\mathrm{t}-1}\right) /\left(\mathrm{P}_{\mathrm{t}-1}\right)$

$\mathrm{R}$ = return saham

$\mathrm{P}_{\mathrm{t}}=$ harga saham pada bulan ke $\mathrm{t}$

$\mathrm{P}_{\mathrm{t}-1}=$ harga saham pada bulan $\mathrm{t}-1$

\section{Metode Analisis Data}

Analisis data yang digunakan dalam penelitian ini bertujuan unutk mengetahui pengaruh variabel corporate governance dan struktur kepemilikan terhadap asimetri informasi. Metode analisis data dalam penelitian ini adalah: 1) Analisis Statistik Deskriptif. Statistik deskriptif merupakan proses transformasi data penelitian dalam bentuk kuantitatif sehingga mudah dipahami dan diinterpretasikan. Tujuannya adalah untuk mengetahui gambaran umum mengenai data tersebut dan hubungan antara variabel yang akan digunakan dalam penelitian
(Ghozali 2006). 2) Uji Asumsi Klasik. Untuk mendukung kebenaran interpretasi hasil analisis dengan model regresi maka dilakukan uji asumsi klasik. Asumsi klasik yang harus terpenuhi meliputi uji normalitas residual yaitu data residual harus normal, non-multikolinearitas, dan homokedastisitas. Namun sebelum model regresi digunakan untuk menguji hipotesis, diperlukan uji asumsi klasik untuk memastikan bahwa model telah memenuhi kriteria Best Linear Unbiased Estimated (BLUE) (Ghozali 2006). 3) Multiple Regression Analysis. Analsis dalam penelitian ini bertujuan untuk mengetahui pengaruh variabelvariabel independen terhadap variabel dependen (Ghozali 2006). Model persamaan yang digunakan dalam penelitian ini adalah sebagai berikut:

$$
\begin{aligned}
A I= & a+b_{1} C G+b_{2} K I+b_{3} K M+b_{4} \text { Size }+ \\
& b_{5} \text { Vol }+b_{6} \text { Return }+e
\end{aligned}
$$

Keterangan:

$$
\begin{array}{ll}
\mathrm{a} & =\text { Konstanta } \\
\mathrm{b} 1-\mathrm{b} 5 & =\text { Koefisien Regresi } \\
\mathrm{AI} & =\text { Asimetri Informasi } \\
\mathrm{CG} & =\text { Corporate Governance } \\
\mathrm{KI} & =\text { Kepemilikan Institusional } \\
\mathrm{KM} & =\text { Kepemilikan Manajerial } \\
\mathrm{Size} & =\text { Ukuran Perusahaan } \\
\mathrm{Vol} & =\text { Volume Perdagangan } \\
\text { Return } & =\text { Varian Return saham } \\
\mathrm{e} & =\text { error }
\end{array}
$$

\section{HASIL DAN PEMBAHASAN}

\section{Hasil Pengumpulan Data}

Penelitian ini dilakukan terhadap sampel yang terdiri dari 155 perusahaan yang berpartisipasi dalan ASEAN corporate governance scorecard pada periode tahun 2010-2011. Sedangkan perusahaan yang memenuhi kriteria dalam penelitian ini berjumlah 120 perusahaan. Data menggunakan signifikansi $10 \%$ dengan tingkat keyakinan $90 \%$.

\section{Statistik Deskriptif}

Untuk memberi gambaran atau deskripsi data dalam penelitian ini dilakukan analisis data deskriptif seperti tampak pada tabel 1 . 
Tabel 1: Statistik Deskriptif

\begin{tabular}{|c|c|c|c|c|c|}
\hline & Maksimum & Minimum & Rerata & $\begin{array}{l}\text { Standar } \\
\text { Deviasi }\end{array}$ & $\mathrm{N}$ \\
\hline Asimetri Informasi (Y) & 2,0663 & 1.6185 & 1,86757 & 0,069907 & 120 \\
\hline Corporate governance (X1) & $89,26 \%$ & $20,81 \%$ & $54,1393 \%$ & $20,11374 \%$ & 120 \\
\hline Kepemilikan Institusional (X2) & $75,55 \%$ & $0 \%$ & $27.1451 \%$ & $14,54533 \%$ & 120 \\
\hline Kepemilikan Manajerial (X3) & $7,93 \%$ & $0 \%$ & $0,3772 \%$ & $1,16174 \%$ & 120 \\
\hline Size (X4) & 8,40 & 5,44 & 7,0859 & 0,57198 & 120 \\
\hline Volume Perdagangan (X5) & 9,22 & 4,02 & 7,7829 & 0,94157 & 120 \\
\hline Varian Return (X6) & 1,7368 & $-0,8249$ & 0,2279 & 0,53819 & 120 \\
\hline
\end{tabular}

Sumber: Data sekunder yang diolah

Tabel 1 diatas dapat memberikan sejumlah informasi, antara lain bahwa $\mathrm{N}$ atau jumlah total observasi pada setiap variabel yaitu 138 perusahaan dengan periode pengamatan 2010-2011, namun dikarenakan adanya data outlier maka data tersebut dibuang sehingga diperoleh jumlah observasi 120 perusahaan. Asimetri informasi disini diukur dengan bid ask spread yaitu dengan harga saham harian. Rata-rata asimetri informasi dalam perusahaan sampel adalah 1,86757 sedangkan standar deviasinya sebesar 0,069907. Nilai standar deviasi lebih kecil dari rata-rata menunjukkan variasi yang kecil antara nilai maksimum dan minimum selama periode pengamatan, atau dengan kata lain tidak ada kesenjangan yang cukup besar dari asimetri informasi dalam perusahaan sampel.

Corporate governance diukur dengan indeks ASEAN CG Scorecard yang dikeluarkan oleh IICD yang merupakan domestic body dari penilaian corporate governance yang merupakan inisiatif dari ASEAN Capital Market Forum (ACMF) yang beranggotakan para regulator dari negera-negara di ASEAN. Rata-rata nilai corporate governance adalah $54,1393 \%$ sedangkan standar deviasinya $20,1137 \%$. Nilai tersebut menunjukkan bahwa terdapat variasi yang kecil antara nilai maksimum dan minimum selama periode pengamatan atau dengan kata lain tidak ada kesenjangan yang cukup besar dari nilai corporate governance. Data maksimum dan minimum adalah $20,81 \%$ dan $89,26 \%$.

Kepemilikan institusional adalah kepemilikan suara yang dimiliki oleh suatu institusi terhadap suatu perusahaan. Nilai rata-rata kepemilikan institusional dalam penelitian ini adalah $27,1451 \%$ sedangkan standar deviasinya adalah $14,54532 \%$. Nilai tersebut menunjukkan bahwa terdapat variasi yang kecil antara nilai maksimum dan minimum atau dengan kata lain tidak terdapat kesenjangan yang cukup besar dari kepemilikan institusional.

Kepemilikan manajerial adalah kepemilikan suara yang dimiliki oleh pihak manajer dalam perusahaan. Nilai rata-rata kepemilikan manajerial dalam penelitian ini adalah $0,3772 \%$ sedangkan standar deviasinya adalah $1,1617 \%$. Nilai standar deviasi lebih besar daripada rata-rata menunjukkan bahwa tingginya nilai variasi antara nilai maksimum dan minimum dalam penelitian, atau dengan kata lain terdapat kesenjangan yang cukup besar dari kepemilikan manajerial.

\section{Pengujian Asumsi Klasik}

\section{Ujin ormalitas}

Berdasarkan hasil pengujian normalitas menggunakan uji Kolmogorov-Smirnov menunjukkan nilai yang lebih besar daripada 0,05 , yaitu 1,32 sehingga dapat disimpulkan bahwa asumsi normal telah dipenuhi sehingga model regresi ini layak digunakan dalam penelitian.

\section{Uji multikolinearitas}

Uji multikolinearitas menunjukkan VIF variabel di bawah 10, yang menunjukkan bahwa dalam persamaan ini tidak terjadi multikolinearitas antar variable, sehingga dapat disimpulkan bahwa tidak terjadi multikolinearitas antar variabel bebas dalam persamaan regresi.

\section{Uji heterokedastisitas}

Uji heteroskedastisitas dilakukan menggunakan grafik scatterplot, hasilnya menunjukkan 
penyebaran titik-titik yang tidak mempunyai pola yang jelas, serta titik-titik tersebut menyebar di atas dan di bawah angka 0 pada sumbu y. Hal ini dapat disimpulkan bahwa tidak terjadi heteroskedastisitas dalam persamaan ini, sehingga persamaan regresi ini layak dipakai untuk penelitian ini.

\section{Pengujian Hipotesis}

Penelitian ini menggunakan analisis regresi berganda (Multiple Regression Analysis) untuk membuktikan hipotesis yang dibuat. Tingkat keyakinan yang digunakan dalam penelitian ini adalah 90\%, jadi tingkat kesalahan yang dapat ditoleransi adalah sebesar $10 \%$. Sehingga jika nilai signifikansi kurang dari 0,10 maka dapat disimpulkan bahwa variabel independen tersebut berpengaruh secara signifikan terhadap variabel dependennya. Dari hasil perhitungan, didapatkan persamaan regresi sebagai berikut ini:

$$
\begin{aligned}
\mathrm{AI}= & 1,842-6,374 \mathrm{E}-005 \mathrm{CG}+0,001 \mathrm{KI}- \\
& 0,010 \mathrm{KM}+0,007 \text { Size }-0,003 \mathrm{Vol}- \\
& 0,033 \text { Return }+\mathrm{e}
\end{aligned}
$$

Koefisien determinasi pada intinya mengukur seberapa jauh kemampuan model dalam menerangkan variasi variabel dependen. Dalam penelitian ini dihasilkan nilai Adjusted R Square sebesar 0,09. Nilai tersebut menunjukkan bahwa $9 \%$ variasi dari asimetri informasi dapat dijelaskan dengan keenam variabel independen dan variabel kontrol yaitu corporate governance, kepemilikan manajerial, kepemilikan institusional, ukuran perusahaan, volume perdagangan, dan varian return. Sedangkan sisanya yaitu $91 \%$ dijelaskan oleh variabel lain atau sebab-sebab yang lain yang berada diluar model. Dari hasil perhitungan regresi yang dilakukan juga didapatkan hasil konstanta sebesar 1,842 hal ini menunjukkan bahwa jika variabel lain dianggap konstan maka variabel asimetri informasi sebesar 1,842 .

\section{Pengujian hipotesis 1}

Pengujian hipotesis pertama (H1) menyatakan bahwa corporate governance berpengaruh negatif terhadap asimetri informasi dengan nilai signifikansi sebesar 0,848 (lebih besar dari $\alpha$ yaitu 0,10 ). Dengan demikian hipotesis petama ditolak. koefisien regresi dari corporate governance ini adalah -6,374E-005. Hal ini menunjukkan bahwa corporate governance tidak berpengaruh secara signifikan terhadap asimetri informasi.

Hasil penelitian ini konsisten dengan penelitian yang dilakukan oleh Klein, Shapiro, dan Young (2005). Namun, hasil penelitian ini tidak konsisten dengan penelitian yang dilakukan oleh Kanagaretnam, Gerald, dan Dennis (2007) yang menyatakan bahwa corporate governance yang berkualitas akan menurunkan asimetri informasi.

Tabel 2: Hasil Penelitian

\begin{tabular}{llll}
\hline \multicolumn{1}{c}{ Variabel Bebas } & \multicolumn{1}{c}{ Koefisien } & \multicolumn{1}{c}{ T-Stat } & Sig. \\
\hline Konstanta & 1,842 & 18,959 & 0,000 \\
Corporate governance & $-6,374$ & $-0,192$ & 0,848 \\
Kepemilikan Institusional & 0,001 & 1,422 & 0,158 \\
Kepemilikan Manajerial & $-0,010$ & $-1,860$ & 0,065 \\
Ukuran Perusahaan & 0,007 & 0,575 & 0,567 \\
Volume Perdagangan & $-0,003$ & $-0,495$ & 0,622 \\
Varian Return & -0.033 & $-2,871$ & 0,005 \\
\hline R Square $=0.136$ & Sig F $=.010$ & & \\
Adj. R Square $=0.090$ & & & \\
F Stat $=2,960$ & & & \\
\hline
\end{tabular}

Sumber: data sekunder yang diolah 
Hampir sama dengan penelitian yang dilakukan oleh Klein, Shapiro, dan Young (2005), dalam penelitian ini tidak terbukti bahwa corporate governance berpengaruh negatif terhadap asimetri informasi. Hal ini dikarenakan oleh dalam penelitian ini menggunakan ASEAN corporate scorecard untuk menilai corporate governance. Scorecard ini menggunakan penilaian dengan standar di Negara-negara ASEAN. Standart yang dilakukan dalam ASEAN CG Scorecard ini lebih baik daripada yang ada di Indonesia, karena di Indonesia peraturan tentang penerapan corporate governance hanya mewajibkan perusahaan publik mengangkat dewan komisaris dan komite audit. Sedangkan penilaian yang dilakukan di ASEAN CG scorecard melakukan penilaian yang lebih baik, penilaian dalam scorecard ini, selain kewajiban adanya komite audit dan dewan komisaris dalam suatu perusahaan, juga mencakup tentang hak-hak pemegang saham dan kesejahteraan karyawan masuk dalam kriteria penilaian bahkan keselamatan pelanggan juga termasuk dalam penilaiannya.

Kriteria penilaian di Indonesia yang lebih sedikit daripada penilaian ASEAN CG Scorecard mengakibatkan score yang didapatkan perusahaan-perusahaan di Indonesia rendah. Hal ini mengakibatkan pengaruh hasil penelitian yang tidak signifikan terhadap asimetri informasi. Karena, nilai corporate governance yang kecil mengakibatkan asimetri informasi yang besar.

\section{Pengujian hipotesis 2}

Pengujian hipotesis yang kedua $(\mathrm{H} 2)$ menyatakan bahwa kepemilikan institusional berpengaruh negatif terhadap asimetri informasi. Berdasarkan pengujian regresi berganda yang dilakukan menunjukkan nilai signifikansi sebesar 0,158 (lebih besar dari nilai $\alpha=0,10$ ) dan koefisien regresi sebesar 0,001 sehingga dapat disimpulkan bahwa hipotesis kedua ditolak.

Hasil penelitian ini didukung oleh penelitian yang dilakukan oleh Purwanti (2013). Dalam penelitiannya Purwanti (2013) menghasilkan tidak adanya hubungan negatif antara kepemilikan institusional dan asimetri informasi. Hal ini bertentangan dengan prinsip transparansi yang menyatakan bahwa semakin besar kepemilikan institusional akan memberikan tekanan yang tinggi kepada manajer untuk memberikan pengungkapan yang lebih baik.

Selain itu, rata-rata kepemilikan institusional dalam suatu perusahaan lebih kecil daripada kepemilikan publik. Hal ini mengindikasikan kepemilikan institusional belum dapat memberikan pengaruh yang signifikan. Dan kemungkinan pihak institusional tidak melakukan pengawasan dikarenakan akan menimbulkan biaya yang besar (Klein, Shapiro, dan Young 2005), karena pihak institusional adalah pemilik yang memfokuskan pada current earnings. Fokus pihak institusional yang hanya pada current earnings ini membuat para manajer melakukan tindakan yang tidak transparan agar investor institusional berinvestasi. Tindakan tidak transparan disini misalnya melakukan manajemen laba, manajemen laba akan mengakibatkan asimetri informasi.

\section{Pengujian hipotesis 3}

Pengujian hipotesis yang ketiga (H3) menyatakan bahwa kepemilikan manajerial berpengaruh negatif terhadap asimetri informasi. Berdasarkan pengujian regresi berganda yang dilakukan menunjukkan nilai signifikansi sebesar 0,065 (lebih kecil dari nilai $\alpha=0,10$ ) dan nilai koefisien regresi sebesar $-0,010$ sehingga dapat disimpulkan bahwa hipotesis yang dirumuskan diterima. Hal ini sesuai dengan prinsip transparansi dalam penerapan corporate governance yang mengungkapkan bahwa semakin tinggi kepemilikan manajerial dalam suatu perusahaan maka pengungkapan informasi yang terjadi dalam perusahaan tersebut semakin tinggi pula, sehingga akan mengurangi adanya kesenjangan informasi yang ada didalamnya.

Hal ini dikarenakan oleh banyaknya perusahaan di Indonesia yang menggunakan manajemen yang berpengalaman dan profe sional. Penggunaan manajemen yang profesional akan membuat transparannya informasi 
yang ada di dalam perusahaan. Selain itu kepemilikan manajerial akan membuat kinerja para manajer semakin baik dikarenakan adanya rasa memiliki dalam perusahaan. Rasa memiliki ini akan mengakibatkan para manajer meningkatkan transparansi dan kinerja perusahaan.

Hasil penelitian ini juga sesuai dengan prinsip transparansi dalam penerapan corporate governance yang mengungkapkan bahwa semakin tinggi kepemilikan manajerial dalam suatu perusahaan maka pengungkapan informasi yang terjadi dalam perusahaan tersebut semakin tinggi pula, sehingga akan mengurangi kesenjangan informasi yang ada didalamnya. Kepemilikan manajerial ini juga dalam hal ini juga akan mengurangi ketidakselarasan kepentingan antara agen dan principal.

Hasil penelitian ini konsisten dengan penelitian yang dilakukan oleh Purwanti (2013) dan Crutchley dan Hansen (1989). Penelitian-penelitian tersebut menyimpulkan bahwa kepemilikan manajerial yang tinggi dapat mengurangi masalah keagenan. Masalah keagenan yang kecil akan mengurangi asimetri informasi antara agen dan principal. hal ini dikarenakan oleh proporsi kepemilikan manajerial atas perusahaan akan menurunkan kecenderungan manajer untuk melakukan tindakan yang merugikan kepentingan principal. Dengan adanya hal tersebut maka kepentingan antara agen dan prisipal akan menyatu sehingga gap informasi antara keduanya akan dapat diperkecil.

\section{SIMPULAN}

Hasil penelitian menunjukkan bahwa corporate governance tidak berpengaruh terhadap asimetri informasi. Hasil penelitian ini tidak sejalan dengan teori yang menyatakan bahwa corporate governance memiliki peran untuk pengawasan sehingga akan memberikan keyakinan kepada investor bahwa dana yang diinvestasikan aman. Tidak adanya pengauh ini dikarenakan penerapan corporate governance yang ada di Indonesia cenderung tertinggal dari negara-negara lain, sehingga menyebabkan tidak adanya pengaruh yang signifikan.
Hasil penelitian yang menguji pengaruh struktur kepemilikan terhadap asimetri informasi menunjukkan bahwa struktur kepemilikan institusional tidak berpengaruh terhadap asimetri informasi. Hal ini dikarenakan oleh fokus investor institusional yang hanya kepada current earnings. Fokus yang hanya kepada current earnings membuat para manajer melakukan tindakan tidak transparan.

Sedangkan untuk kepemilikan manajerial, terdapat pengaruh yang signifikan dengan koefisien negatif terhadap asimteri informasi. Hal ini berarti terdapat pengaruh negatif yang signifikan terhadap asimetri informasi. Hal ini dikarenakan oleh perusahaan-perusahaan di Indonesia saat ini menggunakan manajemen yang profesional dan berpengalaman. Penggunaan manajemen yang profesional akan mengurangi kesenjangan informasi dalam perusahaan. Karena manajemen yang profesional akan menjaga kredibilitasnya sehingga perusahaan yang menjadi tanggungjawabnya akan lebih transparan.

Pada studi ini dapat disimpulkan bahwa corporate governance struktur kepemilikan institusional secara umum tidak dapat mengurangi asimetri informasi. Sedangkan untuk struktur kepemilikan manajerial terbukti berpengaruh terhadap asimetri informasi. Dengan demikian, melalui studi ini dapat memberikan kontribusi untuk mempertimbangkan corporate governance dan struktur kepemilikan dalam sebuah perusahaan untuk melindungi investasi yang akan ditanamkan dalam perusahaan tersebut.

Peneliti menyadari terdapat keterbatasan dalam studi ini. Keterbatasan pertama rentang tahun penelitian yang hanya 2 tahun terlalu sempit. Keterbatasan ini terjadi karena salah satu variabel yaitu corporate governance diproksikan dengan ASEAN Corporate governance Scorecard dimulai pada tahun 2010. Peneliti hanya bisa mendapatkan data tahun 2010 dan 2011, pada tahun selanjutnya data ASEAN corporate governance scorecard belum dikeluarkan oleh domestic body di Indonesia yaitu IICD.

Berdasarkan keterbatasan yang ada di atas, terdapat beberapa saran yang diberikan 
peneliti dalam penelitian selanjutnya. Pertama, peneliti selanjutnya sebaiknya menambahkan tahun penelitian agar dapat mendapatkan hasil yang lebih meyakinkan. Selain itu peneliti selanjutnya diharapkan menggunakan indeks yang lain untuk memproksikan corporate governance. Kedua, peneliti selanjutnya diharapkan dapat menggunakan semua perusahaan yang terdaftar di Bursa Efek Indonesia. Namun jika dirasa sulit untuk menggunakan proksi indeks corporate governance, maka sebaiknya peneliti selanjutnya menggunakan mekanisme corporate governance.

\section{DAFTAR REFERENSI}

Arifin, Z., dan N. Rahmawati. 2006. Pengaruh corporate governance terhadap efektifitas mekanisme pengurang masalah agensi. Jurnal Siasat Bisnis 3 (3): 237 47.

Beiner, S., W. Drobetz, F. Schmid, dan H. Zimmermann. 2003. Is board sizes an independent corporate governance mechanism? Working Paper, University of Basel, Basel, Switzerland.

Cai, J. Y., Y. Qian, Y. Liu, dan M. Yu. 2008. Information asymmetry and corporate governance. Drexel College of Business Research Paper No. 2008-02. Diakses dari http://ssrn.com/Abstract=1082589.

Copeland, T. E., dan J. F. Weston. 1992. Financial theory and corporate policy. edisi ke-5. USA: Addison-Wesley Publishing Company, Inc.

Crutchley, C., dan R. Hansen. 1989. A Test of the agency theory of managerial ownership, corporate leverage, and corporate dividends. Financial Management 18 (Winter): 36-46.

Ghozali, I. 2006. Aplikasi Analisis Multivariate dengan program SPSS. edisi ke4. Semarang: BP. Universitas Diponegoro.

Gideon, L., dan P. Milgrom. 1985. Bid ask spread and transaction prices in a specialist market with heterogeneously informed traders. Journal of Financial Economics 14 (1): 71-100.

Henry, D. 2010. Agency cost, ownership structure, and corporate governance compliance: a private contracting perspective. Pasific-Basin Finance Journal 18 (1): 24-46.

IICD. 2014. Indonesian Institute for Corprate Directorship: Search result." Diakses dari http://www.iicd.or.id/en/searchresult.html? search=Penilaian+corporat e+governance+yang+merupakan+inisi atif+dari+ASEAN+Capital+Market+F orum+\%28ACMF\%29+yang+berangg otakan+para+regulator+pasar+modal+ di+negara + ASEAN\&id $=40$.

Jensen, G.R., D.P. Solberg, dan T.S. Zorn. 1992. Simultenous determination of insider ownership, debt, and dividend. Journal of Financial and Quantitative Analysis 27 (2): 247-263.

Jensen, M. C., dan W. H. Meckling. 1976. Theory of the firm: managerial behavior, agency costs, and ownership structure. Journal of Financial Economics 3 (4): 305-360.

Kanagaretnam, K.L., J.L. Gerald, dan J. W. Dennis. 2007. Does corporate governance reduce information asymmetry around quarterly earnings anouncement? Journal of Accounting and Public Policy 26 (4): 497-522.

Klein, P., D. Shapiro, dan J. Young. 2005. Corporate governance, family ownership and firm value: the canadian evidence. Corporate Governance An International Review 13 (6): 769-784.

Knight, P. J., dan C. Weir. 2009. Agency cost, corporate governance mechanism, and ownership structure in large uk publicly quoted companies: a panel data analysis. The Quarterly Review of Economics and Finance 49 (2): 139150. 
Purwanti, T. 2013. The impact of corporate governance mechanism on the asymmetry information. Jurnal Kiat BISNIS 5 (2): 129-147.

Richardson, V. J. 1998. Information asymmetri and earning management: some evidance. Journal Financial and Economics. Diakses dari http://www.ssrn.com.

Singh, M., dan W. N. Davidson. 2003. Agency cost, ownership structure, and corporate governance mechanism. Journal of Banking and Finance 27 (5): $793-$ 816.

Ujiyanto, M. A., dan B. A. Pramuka. 2007. Mekanisme corporate governance, manajemen laba dan kinerja keuangan. Makasar: Simposium Nasional Akuntansi X.

Wisnumurti, A. 2010. Analisis pengaruh asimetri informasi terhadap manajemen laba. Semarang: Universitas Diponegoro. 